\title{
Body As Media In Action Drawing Titled Metamorposer 6
}

\author{
Luna Dian Setya Avissa ${ }^{1}$, Agus Purwantoro ${ }^{2}$ \\ Program Pascasarjana, Universitas Negeri Sebelas Maret Surakarta \\ Jl. Ir. Sutami No.36A, Jebres, Surakarta, Jawa Tengah 57126 \\ 1lunadiansetyaa113@gmail.com
}

\begin{abstract}
The artist observe her own life and choose metamorphosis of butterfly as a metaphor. The idea of a visual artwork entitled Metamorposer 6 particulary taken from the phase of metamorphosis called pupa stage, the work is about the artist who needs to be alone like a caterpillar in a chrysalis to contemplate her selfish side and the desire to devote to her family. Action of drawing as a form of art is chosen to represent the process of making a distance with the surrounding environment and building a space of seclusion. The artist tried to improve her way of creation through media exploration, she also make some conventional result-oriented drawing on the transparant media prior to her action drawing. The idea is communicated not only through strokes of pigment on the transparent panel but also through a process that unifies the space, time and body as media in action drawing. The blank field on the panel is filled with drawings made analogously by the artist throuh manipulating the alkohol-based permanent marker with her right hand and the execution takes about 16 hours in total. The performance in this action drawing displays the drawing lines that slowly covered the body of the artist in a vitrine or transparent case constructed on a table. The present of the body in the action drawing as one of the media being compared with other previous works of notorious artist in an effort to conclude its meaning, function and experience.
\end{abstract}

Keywords: body, media, drawing, performance

\section{Tubuh Sebagai Media Dalam Action Drawing Yang Berjudul Metamorposer 6}

Seniman mengamati kehidupannya sendiri dan memilih metamorfosis kupu-kupu sebagai metafora. Ide karya seni visual yang berjudul Metamorposer 6 secara partikular berfokus pada fase metamorfosis yang disebut pupa, karya adalah tentang seniman yang perlu sendirian seperti ulat di dalam kepompong untuk merenungkan sisi egoisnya dan keinginan untuk berbakti kepada keluarganya . Action drawing sebagai sebuah bentuk seni dipilih untuk mewakili proses pembuatan jarak dengan lingkungan sekitar dan membangun ruang pengasingan. Sang seniman berusaha memperbaiki cara kreasinya melalui eksplorasi media, ia juga membuat beberapa gambar berorientasi hasil pada media transparan sebelum action drawing. Idenya dikomunikasikan tidak hanya melalui goresan pigmen pada panel transparan tetapi juga melalui proses yang menyatukan ruang, waktu dan tubuh sebagai media dalam aksi menggambar. Bidang kosong pada panel diisi dengan gambar yang dibuat secara analog oleh seniman yang memanipulasi marker permanen berbasis alkohol dengan tangan kanannya. Eksekusi karya memakan waktu sekitar 16 jam secara total. Seniman melalui action drawing menampilkan garis gambar yang perlahan-lahan menutupi tubuhnya yang dipajang dalam vitrine atau kotak transparan yang biasa untuk menyajikan benda seni. Kehadiran tubuh dalam action drawing sebagai salah satu media perlu dibandingkan dengan karya seniman terkenal lainnya yang berbasis aksi dan tubuh guna menemukan makna, fungsi dan menjabarkannya sebagai sebuah pengalaman.

Kata Kunci : tubuh, media, drawing, performance

Peer review : 9 - 23 Agust 2018, Accepted : 3 September 2018 


\section{INTRODUCTION}

Feeling anxious about social status achievement expected by the family as the smallest social institution to be considered a successful person is the main thing being the background of the creation of this art project. Anxiety was caused by the dissonance between personal desires which often considered selfish and childish, with the desire to devote to familiy who want their children soon established economically and financially. Differences in values is the main cause of this conflict, but rebellion will likely only worsen the situation; the dialogue with inner-self and a reflections through the work is a chosen way to make peace with inner-self. Express the emotional and psychological problem subtly through metaphor is a path used in the process of work.

Butterfly metamorphosis chosen as an analogy for the questions of appreciated values in the family, and personal effort to adapt to the values. Butterfly often used to describe women and fragility through the phrase "night butterfly", it also used in the title of Puccini's popular tragic opera play "Madame Butterfly". The fact that the butterfly is an imago or adult insect; which is a most advanced phase in the change process called metamorphosis. Starting from eggs which then hatch into caterpillars, gradually their mouth and feet change and grow wings; make adult insects and larvae seen as being different (Schlaepfer, 2006).

Butterfly wings are thin and can be seen from the two sides, this characteristics have inspired the works of the previous result oriented drawing. In these early works, the artist explored the media such as tracing paper and plexiglass to represent the character of the butterfly. The result- oriented works did not satisfy the desire to represent the most important phase in the process of metamorphosis called pupa. Metamorposer 6 is a work that involves the body as a media of creation. This work departs from the observation of the process of metamorphosis of butterflies. Caterpillars form cocoons or chrysalis in particular processes which are analogous to the human process of make distance and construct his own space.

Chrysalis is not suddenly appear in full form on the bodies of caterpillars, this product is formed slowly from caterpillar outermost layer of skin peeling. It took approximately 11 minutes to the butterfly species Danaus chrysippus to be fully pupate, while the other butterfly species such as Cecropia hyalophora kniting silk cocoon from its saliva. Caterpillars are driven by its natural instinct to do the actions and process of covering of their bodies in a time long enough for the insects with a maximum age of about twelve months.

Motion and effort in building caterpillar cocoon or chrysalis recalled through the process of doodling and stringing a line using an alcohol- based markers on transparent media.
Metamorposer 6 presents the body of the artist who resides in a vitrine made of plexiglass and plywood, artist's body who perform the act of drawing inside of the vitrine slowly covered the artist's body by the drawings she made. The action was carried out for about eight hours in two consecutive days by inviting the audience to witness the event, the process also documented in photos and videos.

The body is the new art medium of this 20th century (Meecham, 2005). There are patterns of interaction between the body as the medium and other media. Body communicates with and through other media by how bodies are represented. Body is always with us, it is probably the least consciusly also conceptualized as a medium. Body is not a stable object we could place in front of us to study from the outside. Instead, bodies are changing, developing, never the same. Because we can do something with and to our bodies and bodies because certainly do things with us, Because we as bodies do things (Ornella, 2014). During the 20th century there have been two major developments in the art world, the one who concerned with formal innovations in making objects such as painting while the second involved with live performance. The first is well documented and avaible to anyone with access to a library, museum or gallery. The second is decidedly anti-object oriented and impermanent in nature, is much more difficult, to trace (Gray, 1993).

Body as a media present directly and interact with other media, this is different from the usual work of a results-oriented drawing. Thebody comes indirectly in the result-oriented work of art and drawing activity tends to be conducted in private; while in "action drawing" the body of the artist is important because the act of drawing itself became a form of performance called symbolic action.

Historically there were some previous artists who use their body and this kind of art form; in the process of academical study such things need to be presented as a reference and comparison. The presence of the body as a media in Metamorposer 6 certainly has some significance meaning and purpose when compared with the previous artist's work, but also likely remain bound by universal and timeless language of the body.

\section{METHOD}

Gustami formulated three main stages of creation from exploration when the artist search the source of ideas, concepts, and the foundation of creation; design is the process of drafting the work and find the best form to represent the idea; and the last stage is embodiment or visualization process of ideas and creation of the work itself (Gustami, 2007). While in 1926, Graham Wallas formulated four stages of the process of creation which consists of preparation, incubation, verification and illumination (Kerr, 2009). During the preparation stage the artist collecting 
the subject of the initial idea, find references, and made observations of something that inspires. The initial idea then narrowed; and the artist start to determine the appropriate way to bring those ideas in the works at the process of incubation. The process continues to verification process where the reference and ideas that have been fused checked and if necessary repaired. the illumination process in which a sketch made in an emotional state at the beginning of the process and then be reviewed objectively and developed (Rothenberg \& Hausman, 1991).

The artist wandering in the world of ideas through reading some books, attending discussion and look her own private life as well as natural and social environment around. An early draft were developed through a process of imagination and finally poured a rough sketch with a ballpoint strokes on paper. In the phase of embodiment, the exploration process repeated and continued with experimentation to find the media in accordance with the ideas and have an uniqueness ; on experimentation the artist also tried some techniques to find the best way of execution of the idea.

\section{RESULT}

Metamorposer 6

The artist take a seat in a vitrine consisting of white table made from the multiplex finished with melamine, and transparent plexiglass case. White table has 60 centimeters heigth from the floor, while the transparent lid measuring 200 centimeters long, 100 centimeters wide and 100 centimeters high. The thickness of the plexiglass used for the case is 3 milimeters. The case has two 5- centimeter-diameter hole that keeps the air circulating inside. Vitrine placed in the middle of a square room, with white wall and floor measuring 7 times 7 square meters. A female figure dressed in white imprison herself, doodling the simplified image of giant milkweed plants on the surface inside of the vitrine, it is done by moving the permanent marker using his right hand to draw.

The drawing started from one corner to another corner of the vitrine, from the bottom to the ceiling vitrine, she rotates up to go back to the corner where she started the drawing. Action drawing executed for two consecutive days for about eight hours each day and be done in a state of fasting, because the execution of the works carried out in the month of Ramadan, when the muslims should fasting from the dawn till dusk. Pigment- based black permanent marker of alcohol slowly cover the fields of transparent vitrine and the artist's figure seem covered in the drawings she made. Audience can observe the process of change from the outside of the vitrine, how the action started with a clean surface till the transparent surface start to filled with layers of the images of giant milkweed plant. Cameras record the events from outside the vitrine for documenting the events in the form of videos and photos.

Black lines that form the image contrasts with the room and the costumes used by the artist. The costum she used

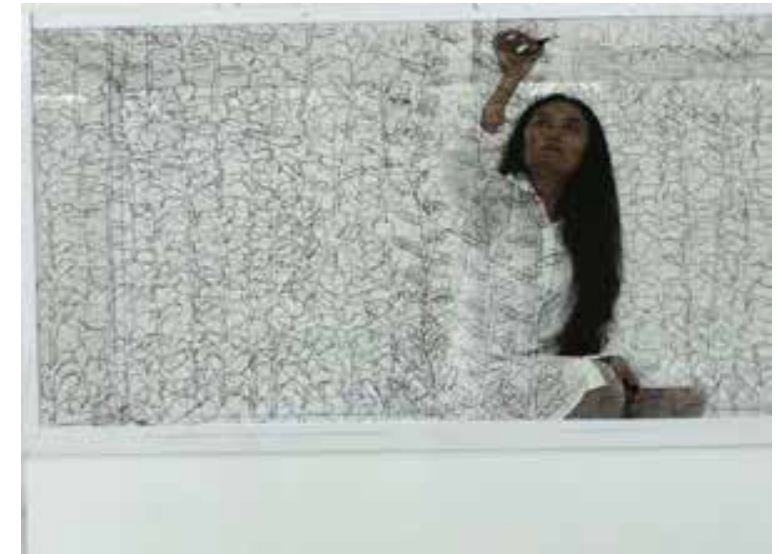

Figure 1. Photo documentation of Metamorposer 6 action drawing by Luna Dian Setya, 2018

consist of a white shirt and white stocking at the first day, by the second day she no longer use the white stocking instead of jeans. People can see the artist clearly at the beginning, as the time counting her images layered by the drawings, so if the audience observed from distance it look like a sheath that composed by layers of marks. The sheath which is made by the artist looks like brocade fabric and translucent like the chrysalis made by the butterflies catterpillar's. The artist look as if she tried to hide herself from the audience through her action.

The action drawing done produced a vitrine which is full of drawings. After the artist came out of the vitrine through one side of thecase that can be shifted and re-closed, vitrine left empty. The drawings on the vitrine become the trace of artist's existence, it became used things as the performance finished and it also stand as results of the action; such as abandoned chrysalis butterflies. Vitrine with the uncountable marks of drawing become an artefact.

Done the action drawings in the vitrine for more than 8 hours is not a comfortable thing for the artist, less air circulation makes the temperature inside hotter than outside, and moisture from respiration sometimes make the surface grew into moist so that the pigment is not easily attached. The body of the artist pressed to fight to the limit in a state of hunger, thirst and lack of oxygen; all of the combination quite risky for the health of the artist, because there is danger of intoxication by the alcohol fumes used as base in the permanent marker. When she came out of the vitrine, the smell of alcohol burst out. Imagine how cool the real caterpillar inside the chrysalis, and what a perfect design of the chrysalis it allows the pupa to breathe in it.

\section{Body as Media in Action Drawing}

Long before Metamorposer 6 are present in the form of action drawing, there has been some notorious artist that presents the body as part of the work. The presence of the body with all it's function and adaptability make the work has a performative nature. Artists ranging from Yves Klein, Jason Pollock, Shigeko Kubota, until Rega Ayundya using their body. They presented the body and the process of making as the important part of their works. 
Rosenberg who was a poet conceived the term action painting in an essay in Art News in 1952 (Diggory, 2013). For Rosenberg, abstract Expressionism is "action painting", it is an act of performance within the arena of the canvas, it is about the intrusion of the body of the artist at the expense of the subject matter, and the art of making a mark through the movement of this body enacts, performs and makes into representation. What was to go on the canvas was not a picture but an event (Jones, 1998).

In the wake of postmodern dissolution and dispersal of the subject, we are witnessing a resurgence of interest in the re-presentation of the body. The body is the thresold of subjectivity, the point of intersection between the private and public, the personal and political. The most radical turn of contemporary art is the return of the repressed, the return of the real body, the expressive space by the which we experience the world. The body has never dissapeared entirely from the sphere of self- representation but the body became other bodies. The visible body becomes a media for art creation and also metaphor for something that is not there (Westley, 2008).

The body is present not only as a model for drawing and painting. Controversial work of Yves Klein titled Anthropometri explicitly using the human body as a tool of painting, she uses female model covered with body paint and then dragged to the surface of the canvas which was held on the floor like a human brushes. The work of Yves Klein later much criticized for exploiting women's bodies.

In 1949 the canvas was dripped and poured on by Jackson Pollock (Rush, 2005). Jason Pollock is one of the artists of abstract expressionism movement that is present directly in the physical action of painting. Rosenberg saw Pollock conception of painting as an act of penetration, involving the ejaculatory activity of "dripping paint" from sharp phallic objects onto a "resistant" surface exposes what is at stake in the particular embodiment of the artist. For Rosenberg the body of the action painting the artist is not the particularized enactment of the visible articulation of the author function Pollock but rather is dematerialized in to a universalized trope of individualist freedom. the body Pollock merged with his painting in a pure harmony of disembodied creation, his body passed into union with his conciousness through releasing paint in fluids that directly record of his physical movements. Pollock's body is considered as a vessel of the "creative masculine" energy. In 1965 the female artist of Japanese descent living in the United States named Shigeko Kubota response "against" heroic and masculin action performed by Pollock with his work entitled "Vagina Painting ". In her work she utilizes her sex as the source of artistic production. Kubota activates the site of the vagina as the originary point of the meaningful painterly gesture (Jones, 1998).

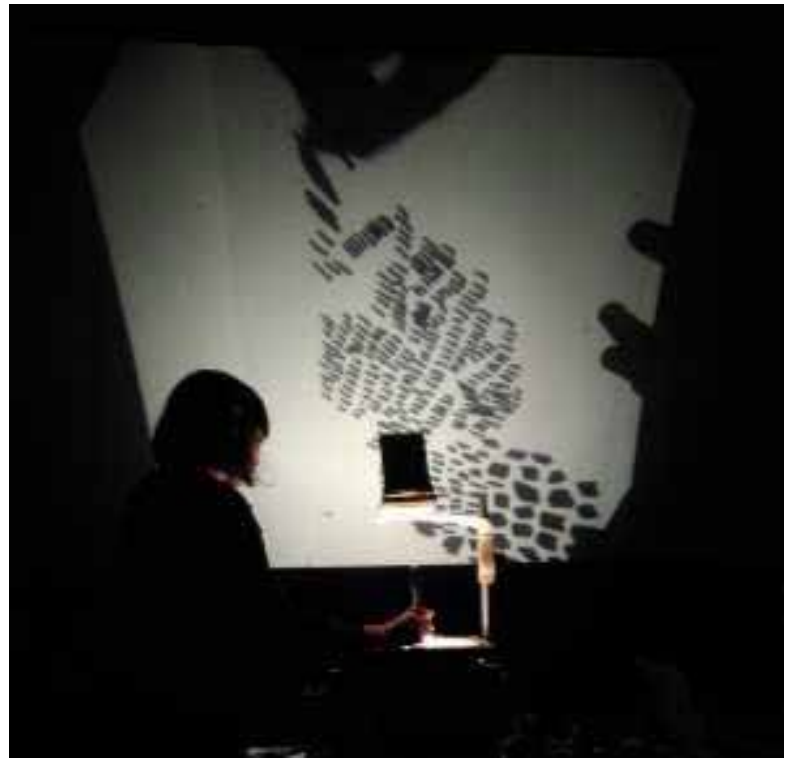

Figure 2. Photo documentation of Primal Nerve action drawing by Rega Ayundya, 2018.

While in 2017, Rega Ayundya a young Indonesian drawing artist is one of the guest artist invited in the event titled Body Out held by Dewan Kesenian Jakarta. In a work titled Primal Nerve she was drawing on a transparent mica presented live using the over head projector in a theater with a capacity of 50 people for 30 minutes. The surface of the projector is attached with a microphone and speaker so that each action of pulling the line and knocking points with marker can be heard loudly by the entire audience. In her action she sat beside the projector, she drew while displaying the images and sound of the pulling lines and knocking points. The drawing process done by Ayundya produced sustained rumbling sound in the room, the sound disturbing and hypnotize the audiences who are not allowed to go out of the room. The audience remain silent and passive.

\section{CONCLUSION}

Butterflies have a life processes that can be compared to the process of human life; but both of these creatures have remained distinct. Human remains sentient while upholds the values derived from their ratio, while butterflies are insects that live by their instinct to survive and reproduce. Despite their complex nature the human being who have their senses and values are not necessarily better than the insects that live only by submits to instinct and vice versa. Human beings are endowed with free will, but they will never be free of the values generated by their own sense. Sometimes they imprisoned by the social and psychological costruction they made.

Construction produced by human is not necessarily better than what is made by the caterpillar. Caterpillar may feel comfortable "meditating" in a chrysalis they instinctively produced, while in Metamorposer 6 artist struggling with discomfort in the "chrysalis" constructed by herself. 
Body with each of its members has the potency to be present as a media because it is physical characteristic so it can be viewed as well as in contact with other physical objects. Each member of the body also has their own meaning, every muscle movement either utilize the big muscles like a hand or a smaller facial muscles will produce something known as expression. The body can stand alone as a media and may also cooperate with other media to produce artistic action.

The body can manipulate other body as has been done by Yves Klein. Body of men and women differ not only physically but also socially, so that his presence would have different meanings. Each member of the human body have their own function and different meaning, thus manipulating the painting brush with hand will have a different meaning to manipulating the painting brush with sex organ as has been done by Kubota. The body can produce sounds with or without interaction with other objects. Body interaction with other media not only produce motion and shapes that can be enjoyed visually, but also sound that can affects the audience.

Body in Metamorposer 6 is the body that creates physical and psychological construction. The artist's creates a barrier between herself and the surrounding environment constructed a space of seclusion. Artist mimicking caterpillar but she did not become a caterpillar, she remained herself in the mind as well as physically; she is a human being who changed the world around her by thinking and creating something. The artist's physical body became part of her own drawing. She left the audience passive and silent. The images she made in the performance all depend on her effort to keep drawing process flowing although dehidration and hypoxia threatened. Discomfort feeling experienced by the artist during the process of performing the work is a challenge in the creative process which involving the body.

\section{ACKNOWLEDGMENT}

The author would like to thank Deny Tri Ardianto, Agus Purwantoro, Narsen Afatara and Nooryan Bahari for the support. The author is also grateful to Melati Suryodarmo for sharing the knowledge. This work might not have been possible had it not been for the efforts and encouragement of all the art gurus the author have met.

\section{REFERENCES}

Diggory, Terence. (2013) Encyclopedia of The New York School of Poets. Facts On File, New York.

Gray, John. (1993) Action Art: A Bibliography of Artist Performance from futurism to Fluxus and Beyond. Greenwood Press, Wesport, Conn.
Gustami, Sp. (2007) Butir-Butir Mutiara Estetika Timur, Ide Dasar Penciptaan Karya, Prasistwa: Yogyakarta.

Jones, Amelia. (1998) Body Art / Performing the Subject. University of Minnesota Press, Minneapolis.

Kerr, Barbara A. (2009) Encyclopedia of Giftedness, Creativity and Talent 1. SAGE, Los Angeles.

Meecham, Pam \& Sheldon, Julie (2005) Modern Art A Critical Introduction, Routledge, NY.

Ornella, A.D., Knauss, S., Hopflinger, A., \& Verlagsgesellschaft, N. (2014) Commun (icat) ing Bodies: Body as Medium in Religious Symbol Systems.Nomos Verlag, Zurich.

Rush, Michael. (2005) New Media in Art. Thames and Hudson Ltd, London.

Schlaepfer, Gloria G. (2006) Butterflies, Marshall Cavendish Benchmark, New York.

Westley, Hannah. (2008) The Body as Medium and Metaphor. Rodopi, NY. 